\title{
Political discourses in fashion: the collective Estileras, a semiotic analysis
}

Cláudia Regina Garcia Vicentini

PhD, Universidade de São Paulo / claudiagarcia@usp.br Orcid: 0000-0002-5059-4271/ lattes

\section{Yasmin Alexandre Có}

Master, Universidade de São Paulo / coh.yasmin@gmail.com

Orcid: 0000-0002-4233-7395 / lattes

\section{Suzana Helena Avelar}

PhD, Universidade de São Paulo / suzana.avelar@usp.br

Orcid: 0000-0002-0831-9652/ lattes 


\title{
Political discourses in fashion: the collective Estileras, a semiotic analysis
}

\begin{abstract}
Fashion is a place of production of meaning in which social values are concretized plastically, enabling the transmission of the most varied and often antagonistic discourses. In this way several social groups are constituted with contesting narratives or reaffirming hegemonic values and tendencies, confirmed plastically in the adopted dress systems. In the wake of this thought we aim to analyze the discursive resources used by the collective Estileras on its page in a social media. This collective is positioned as a "place" for experimentation and transgression of dress norms sanctioned by contemporary society. The theoretical framework of Discursive Semiotics, developments in sociosemiotics and Michel Foucault's notions of power will be adopted in order to account for the complexity of the verb-visual discourses exposed by the collective.
\end{abstract}

Keywords: fashion. Politics. Semiotics. Social media. 


\title{
Discursos políticos na moda: o coletivo Estileras, uma análise semiótica
}

\begin{abstract}
RESUMO
A moda é um lugar de produção de sentido em que os valores sociais se concretizam plasticamente, possibilitando a veiculação de discursos os mais variados e muitas vezes antagônicos. Deste modo diversos grupos sociais se constituem com narrativas contestadoras ou ainda reafirmando valores e tendências hegemônicas, confirmadas plasticamente nos sistemas vestimentares adotados. Na esteira deste pensamento objetivamos analisar os recursos discursivos utilizados pelo coletivo Estileras em sua página em uma mídia social. Este coletivo se posiciona como um "lugar" de experimentação e transgressão de normas vestimentares sancionadas pela sociedade contemporânea. O referencial teórico da Semiótica Discursiva, os desdobramentos da Sociossemiótica e as noções de poder de Michel Foucault serão adotados a fim de dar conta da complexidade dos discursos verbo-visuais expostos pelo coletivo.
\end{abstract}

Palavras-chave: moda. Política. Semiótica discursiva. Mídia social. 


\title{
Discursos políticos de moda: el colectivo Estileras, un análisis semiótico
}

\begin{abstract}
RESUMEN
La moda es un lugar de producción de significado en el que los valores sociales se materializan concretamente, permitiendo la transmisión de los discursos más variados y a menudo antagónicos. De esta manera, diversos grupos sociales se constituyen con narrativas en disputa 0 reafirmando valores y tendencias hegemónicos, confirmados plásticamente en los sistemas de vestimenta adoptados. A raíz de este pensamiento, nuestro objetivo es analizar los recursos discursivos utilizados por el colectivo Estileras en su página de redes sociales. Este colectivo se posiciona como un "lugar" para la experimentación y la transgresión de las normas de vestimenta sancionadas por la sociedad contemporánea. Se adoptará el marco teórico de la semiótica discursiva, el desarrollo de la sociosimiótica y las nociones de poder de Michel Foucault para dar cuenta de la complejidad de los discursos verbal-visuales expuestos por el colectivo.
\end{abstract}

Palabras clave: Moda. Política. Semiótica discursiva. Medios de comunicación social. 


\section{INTRODUCTION}

One of the principles of fashion is to stay within aesthetic standards that are already socially sanctioned. Based on this argument, we began our reflection by appropriating the notions of power in Michel Foucault by saying that society creates control mechanisms that act on the body, making it docile, productive and submissive.

In order to illustrate this process, we aim to discuss contesting traits expressed in discursive fashion practices, thus, this article presents statements in circulation in the media, especially from a Brazilian collective of experimental fashion called Estileras, analyzed from the perspective of Semiotics Discursive, of the unfolding of Sociosemiotics proposed by Eric Landowski and Michel Foucault's notions of power, in order to reflect on other possibilities for the construction of clothing systems that express autonomous narratives in their plastic and material choices.

The collective Estileras, a pun on the stylist, appeared in mid-2015, conceived by Ricardo Boni and Brendon Xavier with a proposal for dress arrangements that do not define clothing by gender, but also do not understand themselves as agendas. These rearrangements and displacement of functions of an object, both clothing and accessories, are very frequent on its social media page Instagram. It is through this digital medium that they communicate with their followers and show their work, and since this is a wide-reaching social media we ask ourselves about this relationship between what Lipovetsky (1989) talks about how fashion enhances the pleasure of seeing and being seen, to display a reframed, edited body on Instagram. 


\section{THEORETICAL FOUNDATION AND RESEARCH METHODOLOGY}

\subsection{Fashion and power}

For Foucault, power must be understood in a wide spectrum that includes not only repression, but also a productive network that crosses the social body and the individual bodies. Power, seen from this angle, produces things, knowledge and discourses, and this is how it gains legitimacy. (FOUCAULT, 1975). Unlike the common understanding, its mechanisms act on individuals regulating "what they are, will be or can be" (FOUCAULT, 1975, p. 21) "Power relations have an immediate impact on the body, mark it, direct it, they subject it, force it to ceremonies, demand signs "(FOUCAULT, 1975, p. 22). Its action takes place through minimal processes of different origins: "[...] small cunning endowed with a great diffusion power, subtle arrangements, of innocent appearance, but deeply suspicious [...] (FOUCAULT, 1975, p. 24 ), which, even though they can be distinguished according to the fields of application, are based on each other and converge to gradually outline a general method of control.

From these considerations, we can relate the fashion system as a type of mechanism that contributes to the establishment of a general control method that Foucault talks about (CÓ; VICENTINI, 2018), in which everyone follows a certain order that is automatically imposed. Fashion sociologist and scholar, Yuniya Kawamura (2005), tells us that the fashion system is institutionalized, and the individuals related to it share the same beliefs, contributing to the permanence of a dominant fashion culture, reiterated by production fashion, as the author says: "The system consists 
of several subsystems composed of a network of designers, manufacturers, wholesalers, public relations professionals, journalists and advertising agencies" (KAWAMURA, 2005, p.45) that is, all they need to be recognized and legitimized by the other actors involved in cooperation activities, and in which the consumer also participates (KAWAMURA, 2005).

This idea corroborates the fact that, in Fashion, there is a kind of hierarchy in which the stylist's discourse of authority occupies a central position, closely followed by all those who, in some way, participate in this circuit, notably the digital influencers or contemporary digital influencers.

We can understand the position of digital influencers, as people who maintain pages on social media, putting themselves as holders of authority speeches about behavior and consumption. Many brands of clothing, cosmetics, shoes, food and a number of others use the credibility of these people to advertise their products. The traditional way of doing marketing is established here, but with a new "guise", that of social media, by reiterating the role of the fashion creator as someone who has knowledge and rules disseminator, since as VICENTINI and CASTILHO say (2008) the clothing conveys aesthetic and symbolic values of a certain time.

However, it is necessary to think about the fashion system based on what BERGAMO (2007, p. 70-71) says, in which it consists in the manifestation and renewal of the symbols of authority and "natural" social distance. The choice of which individuals may or may not occupy the hierarchical spaces of creation is subject to the conformity that their actions demonstrate to have certain expectations: "[...] of behavior, of tastes, of value judgments, of social spaces to be filled [...] "(BERGAMO, 2007, p. 69-70).

The figure of the stylist defines a "right to belong", mentioned by Bergamo (2007), which is nothing more than 
permission to enter the field of creation, the legitimation of a "right" that the individual, through his shares, proves to have to occupy the space of creator. In this way, the territory of creation remains inaccessible to those individuals who do not demonstrate to have the qualities defined by society as those of a creator, thus despite the apparent freedom of access that currently has with the advent of social media, in which "the figures of authority "of media speeches and style sanctions would be closer to ordinary people in a digital interaction, this does not happen in practice.

\subsection{The theoretical tooling of Discursive Semiotics and Sociosemiotics}

Discursive or French line semiotics as it is also known was developed by Algirdas Julien Greimas and his collaborators, when they understood that communicational phenomena are texts that can "be read" or, even, as speeches. In semiotics, we understand that the object-text is articulated in two planes: the content plane and the expression plane. The content plane is the plane of ideas, of semantic elements, in which the values of a time or social group are conveyed, and the plane of expression is the way in which these ideas are realized. The same idea or values of a society can be realized in different ways.

The meaning of this text is studied not only by the detailed description of everything that composes it, but with the concept of "relationship" as fundamental to the description's detail, which is worked on by the way these units are articulated. In this construction, the traits that are repeated are shown. Its action on the enunciatee (subject) is due to the manipulation strategies made by the enunciator (clothing 
designer, stylist, brand, etc.) when articulating the relations of meaning in a certain way.

In order to account for the meaning effects of a given text, semiotics assumes that there is a generative path of meaning underlying it and that it can be divided into three levels, as we will explain below.

The fundamental and most abstract level in which the semantic axes of discourse are structured and in which the opposite categories of meaning occur, example: nature $\mathrm{x}$ culture; freedom vs. oppression, etc.

The intermediate narrative level is that in which the elements of the fundamental level are transformed into objects and values and in this level the transformations of the subject and the value objects that are important in this construction are analyzed.

And, finally, the discursive level, more concrete, in which the narrativity is covered by themes and figures. The choice of these shows the marks of the subject of the enunciation. At this level it is possible to perceive, as José Luiz Fiorin (1998) says, how themes not present in the natural world are dealt with in a given society and at a given time, such as: freedom, in which figures of speech are used to cover the freedom theme, such as: beach vacation. It is important to note that the relationships between themes-figures reveal an ideological universe in which the worldview of a given social class is shown, in which the addressee of the discourse is inserted.

On the internet, television, cinema, for example, texts are syncretic because they are composed of more than one type of language, which are articulated with each other. To account for this type of text, in addition to the Content Plan, it is necessary to analyze the Expression Plan in which the marks of the discursive level are then reiterated by elements called 
formants: the mathematical formants (related to the materiality expressed in the speech), eidetics (say respect to shapes), chromatic and finally, topological (category that concerns the spatial organization of formants). The plan of expression and its formants were studied by Jean-Marie Floch, a disciple of Greimas, and a researcher in the area of advertising.

\subsubsection{The contributions of sociosemiotics}

The technological complexity of the means of communication currently available, unfolds in the multiplicity of syncretic texts that are developed by and for these means, resulting in the most diverse modes of interaction by offering a large number of possibilities for the construction of meaning for the enunciatee of his texts, in which the intelligible mixes with the sensitive. As a reflection of the zeitgeist marked by the "image and the sensitive" (SODRÉ, CAPARELLI, SQUIRRA, 2005. p.10), semiotics oriented their studies towards what Greimas called a "Semiotics of the Sensitive" and in his last book De I ' Imperfection (1987) or Da Imperfição translated and released in Brazil in 2004, in which it dealt with the meaning "lived", in its construction "in action", detaching itself from the text itself, and seeking to understand the meaning given in relationships everyday life, "individual practices" and sensory aspects. (FECHINE, 2006, p.3) The refinement of the means and forms of communication provided an extension of the theory, in which Professor Eric Landowski, a Greimas collaborator, then deepened his studies. The sense in which the apprehension occurs in the very act of feeling, guided these researches, showing that it is possible to work with objects that are constituted and disintegrated, that is, they are not static, or even, as the author says, not sociosemiotics 
it intends to describe objects and in this to correlate the meanings of the productions and significant manifestations, but rather the analysis of the processes in which the interactions between subjects, and subjects and the world around them occur. (LANDOWSKI, 2014. p. 3). From this, there is a change in the way these objects are treated at the narrative level, which until then accounted for a manipulation in which the subject's state was transformed by a desire / duty / power, entering into conjunction with a certain objectvalue. especially for the characteristics that are imposed in the subject-object relations. According to Landowski, there is a need to think of sociosemiotics as an instance of studying "(..) meaning production should not be taken as representations of the social", on the contrary, they are, as the author says, "processes". (LANDOWSKI, 2014, p.13) The model described by Landowski, proposes new meaning regimes, focusing on interaction regimes, as shown in the figure below:

Picture 1. Model by Landowski

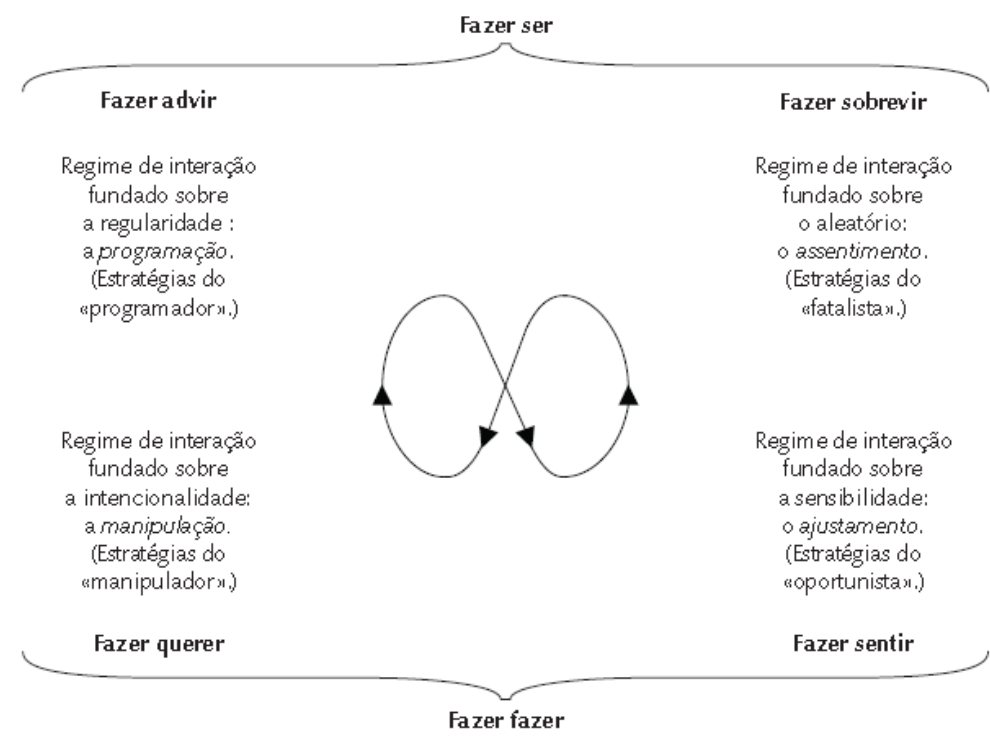

Source: LANDOWSKI, 2014, p. 72. 
Thus, according to the model above, the interaction regime based on programming is that of minimum risk, based on regularity, translated into social constraints, rules, etc. without changing the role of the subject as it is based on know-how. The assent based on the random, according to the author, is also the regime of the accident, that is, the uncertainty accepted by the subject. In the case of adjustment, which should not be confused with adaptation, as Landowski reminds us (LANDOWSKI, 2014, p. 17), there is no need for one subject to bend the other's will, as in manipulation. At this point, the idea of contagion arises in which the subjects come into direct contact, based on their sensitive qualities, referring to the logic of the union. According to the author: "(...) Its exercise supposes, on the part of the subject, the overcoming of the way of reading the world defined by the recognition of specific figurative units, and a disposition to capture effects of meaning derived from the plastic qualities proper to the objects apprehended in his presence immediate whatever their actuarial status (human partners, works or objects from the natural world)" (LANDOWSKI, 2014, p. 17). In this way, the author explains to us that esthetic skills are necessary for the adjustment to take place, and that, in this case, the meanings described by A. J. Greimas in Da Imperfection (2002) about accidents are taken

Esthetics, in which esthesia is directly linked, however, in this regime of interaction they are not linked to the accident, but rather to the effects of meaning emerging from the aesthetic qualities. (LANDOWSKI, 2014, p. 18) The manipulation regime, on the other hand, is based on the fact that one of the subjects has an intentional persuasive role over the other, based on the acquisition of modal 
competences, as previously mentioned. Thus, Landowski presents us with a "grammar of the sensitive" in which the notions of contact, reciprocity and adjustment are fundamental to the configuration of contagion. Based on these premises, Fechine, when proposing the study of media, alerts us to the problem established there in which the description and analysis of the object takes into account the meaning that emerges from the situation that is being built in action. And in this way, to understand how in these enunciative instances these utterances are constructed.

\subsubsection{For a semiotic of fashion}

As it is possible to deduce from what was said above, fashion can be considered as a text in which Plans of Content and Expression are articulated to form meaning and thus convey the values of a given society at a given time. Thus, Vicentini (2010) says that clothes can reconstruct the body through modeling, adding shapes and fabrics, creating contrasts. These resources have been used throughout history by several civilizations between "a game between being and the opinion that is renewed each time" (VICENTINI, 2010, p. 63). Furthermore, fashion can bring ideological positions. This social character has been very evident, showing clear signs of social, political and cultural changes. (VICENTINI and CASTILHO, 2008; VICENTINI, 2010) Thus, fashion in its clothing object-text brings in figurativized social discourses that are perceived in the arrangement of its expression plane, in which in this visual text material, chromatic, eidetic elements are placed that in its plastic arrangement reiterate or deny social values. So that semiotics makes an undeniable contribution to this reading when exploring the possibilities of communication, whether obvious or not, the body-dress then 
assumes modes of presence, cultural, resignified, in line with its time, conveying values of social environment in which it circulates.

\section{INSTAGRAM AS A TERRITORY OF CREATION AND VISIBILITY}

Created in 2010 to be an online social media for photo sharing, today, Instagram is among the most used social media among young people and adults, and currently has more than 600 million users, with research showing that more than 400 million of these are active daily. This digital platform is configured by an account in which the user has the right to set up a page with a summary of his personal and contact information. From this, it is available the possibility of inserting photos with texts to be seen by the followers of the page. Since its creation, this media has incorporated resources in order to remain attractive and today it has the possibility of inserting short videos, various types of filters ${ }^{1}$ and possibilities for quick interaction with those who follow the page. Semiotically speaking, these digital platforms are structured in a plurality of languages, in which the enunciative strategies constitute a whole of meaning, and are reiterated in the Plan of Expression. (FIORIN, 2009). This whole of meaning, or in short, this syncretic text, places the various pages of Instagram as enunciators speaking to a subject (enunciatee) that we assume is in search of an object-value, that is, the subject seeks something with which he is in a situation of disjunction, something that he somehow wants. The enunciative strategy of social media modalizes this subject to a will, in order to come into conjunction with its alleged object-value. Instagram is then constituted by a large number of pages of ordinary people and other famous people, 
celebrities in the area of entertainment, politics, commercial pages of large and small companies of the most varied segments, etc. forming a large network of followers and followers. The construction of modes of presence is due to the verification effects of these enunciators, that is, the credibility they have and thus the power to influence the enunciatees. $A$ survey conducted in the UK found that $82 \%$ of respondents believe that social media sets standards of beauty. (SILVEIRA, 2014), corroborating the fact that there are celebrities whose Instagram page has millions of followers. In addition, it is worth mentioning the interesting phenomenon in which ordinary people gained fame from an "image projection" in this media, by placing themselves as holders of knowledge valued in contemporary society.

In this media the image is the text, so aesthetic and behavioral simulations can be constructed that reinforce socially legitimated standards. This can be assessed by the number of followers on a page belonging to one of these celebrities legitimizing these standards. Among the famous personalities on Instagram in Brazil for broadcasting fashion content, Vogue Brasil in a 2018 report highlighted the socalled fashionistas Thassia Naves, Camila Coelho, Camila Coutinho, Luisa Accorci, Vitória Ceridono as fashion references to be followed on social media. In these profiles we can find an aesthetic pattern of long bodies and a Eurocentric beauty reference: all are white, thin, proportional body and face, extremely photogenic. These profiles meet the standard of beauty, youth and vigor, celebrated by Western culture. Just to make our line of thought clearer, below are two images from the Instagram profile of these digital influencers, chosen at random; Thassia Naves, with 3.5 million followers and Camila Coelho with 8.4 million. When analyzing the images, it is possible to perceive the use of photographic resources for 
image processing, such as: light, shadow, saturation, etc. The scenario is carefully organized so as not to cause "noise" in the message. The clothes shown in the images are always the latest trends in the fashion industry for the time, as you can see in the image below:

Picture 2. Thassia Naves

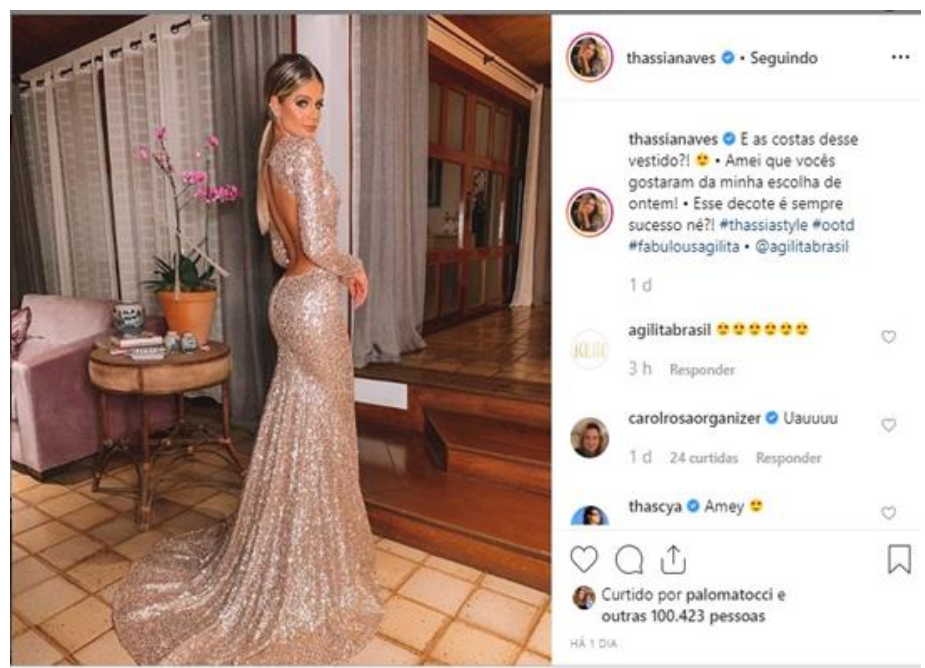

Source: Instagram, 2019.

Picture 3. Camila Coelho

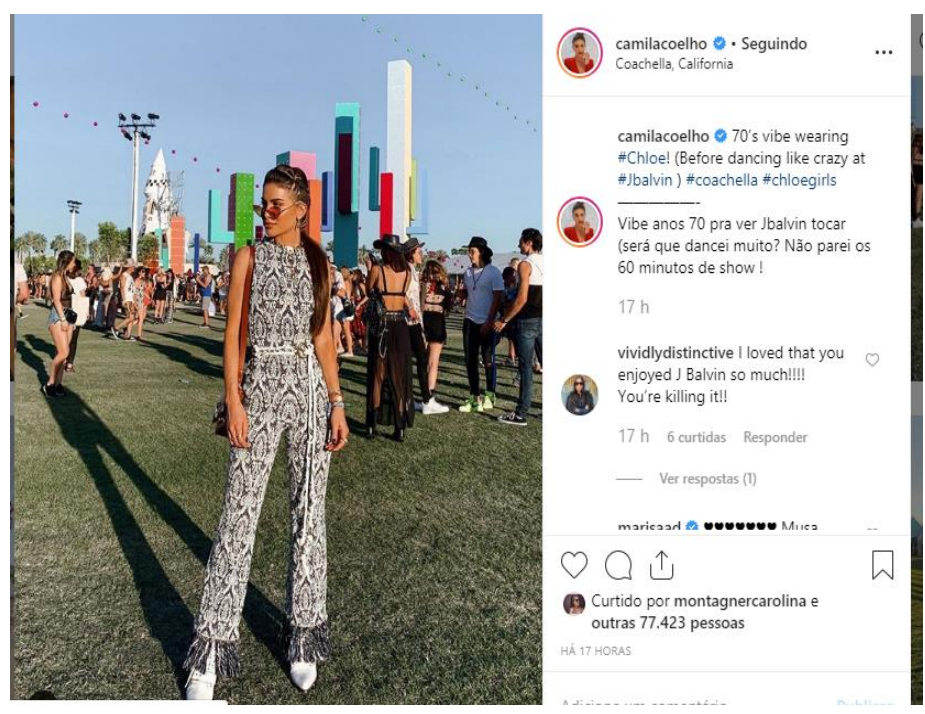

Source: Instagram, 2019. 
As we can see in the images above, these are similar to the fashion advertisements published by magazines in the segment, but with a few differences, in this case, the clothing is being divulged by a recipient (fashionista) who creates a simulacrum of intimacy with the follower of its profile, a fact reiterated by the small text that accompanies the image that is perceived as a suggestion, or advice of what can be used. Thus, it is pertinent to say that this subject "seeking to make himself seen, will organize the device required to capture the eye of a potential observer" (LANDOWSKI, 2002, p.89.) Thus, the discursive resources are placed at the service of this relationship that establishes itself of supposed complicity in which the enunciator fulfills his role of manipulating the enunciatee to believe in his speech leaving the marks of that enunciation. As Fiorin (1998) says, manipulation (belonging to the narrative level) will be covered by themes and figures at the discursive level, with which the enunciatee identifies. In the case of these examples above, there is a kind of connection with the follower of the page, established and reiterated by the expression plane when Thassia Naves is placed looking at the camera, as if challenging the enunciatee. The words next to the image reinforce this idea when he says: "And the back of this dress ?! I loved that you liked my choice yesterday $(. .$.$) ", so the speech establishes a" me "that$ interacts directly with a" you ", reiterating the effect of proximity.

In figure 2, taken from the profile of Thassia Naves, the environment in which the photo was taken is apparently that of a house, in which the sofa, windows, lamps, elements that represent a dwelling in the background can be seen. Perhaps from herself, but that is not made explicit at any time. When analyzing the chromatic formants we have that there is a color 
point next to it, pink, referring to the flowers, which contrasts with the nude tone, next to the beige, a color considered neutral, of the dress. This contrast establishes these flowers as the focal point, leading the enunciatee's gaze to the dress. It is also interesting to note in the plane of expression the eidetic formants of the sofa (rectangular), windows (rectangular and square) and the table (round) on which the vase of flowers is supported. Thassia Naves is placed next to the table, and it is possible to see the contrast between her longitudinal (vertical) figure and the other figures in the scene, in which her figure stands out.

In the other image (figure 3), the visual language of contrasts of the chromatic formants strategically placed in the scene are once again used as resources. Camila Coelho, is in a place that resembles a park, outdoors, with colored pilasters in the background, in red, blue, green, white that direct the look to her figure. In this case, the eidetic formants of the scene, reiterate the main vertical form proposed by the enunciator Camila. In the two images, contrasts of chromatic formants are used as predominant visual languages in the expression plane, this type of language is used to emphasize certain elements of a composition, however what is interesting to note is that these expression planes, despite the contrasts used, are markedly harmonic. There is balance in the arrangement of the elements, causing no visual discomfort. These traits reiterate in the content plan values related to what is beautiful, or socially accepted. A certain feminine role is also reiterated, in the delicacy of the chosen clothing in which the feminine forms are emphasized, but in a way in which harmony is noted. The dress used is completely molded to the body, in the case of Thassia Naves, which, due to its materiality and brightness, evokes an object dressing, which occurs through the encounter with the other. (GARCIA, 
2005) But, from this little reading, what can we infer from these roles? When we shed light on this object, what can be inferred is that the feminine role built by the enunciatorThassia Naves and Camila Coelho are consistent with that in which the woman has a decorative and docile appeal, with garments that outline the particularities of the female body, reaffirming the gender, but without excess, to the taste of the patriarchal society.

In this way, the ideas proposed by Foucault are materialized in the power, disciplinary relationships that are established in these relationships, in which simulations of beauty and good taste are placed to be followed. They are, as we can see, docilized, disciplined bodies, in line with the gender that is biologically attributed to them, being the discipline according to the author, a means of controlling the production of discourse When we take into account the expressive numbers of followers that have both examples that we have brought to this discussion, these disciplinary devices are finding space for reverberation. (FOUCAULT, 1987) But. on the other hand, there is space on Instagram for another type of discourse that opposes what was explained above and shows other possibilities of modes of presence, in which the current aesthetic standards are criticized. Michel de Certeau (1998) shows in his book, The Invention of Everyday Life, a reflection on the microphysics of Foucault's power, in which he discusses the disciplinary mechanisms embedded in everyday life. The "ways of doing" through which individuals reappropriate the space organized by control techniques, to form an antidisciplinary network. To these "ways of doing" that are opposed to the strategies of power, Certeau gives the name of tactics: "surreptitious forms that are assumed by the dispersed, tactical and bricolating creativity of groups or individuals now trapped in the networks of" surveillance " 
"(CERTEAU, 1998, p.41). And yet, these strategies, so to speak, "[...] hide their relationship with the power that sustains them, kept by the institution or by the institution" (CERTEAU, 1998, p.47). The escape tactics, in turn, are punctual victories for those who have a non-place in a territory that does not belong to them, but from which they cannot escape entirely. They are: "[...] small successes, arts of striking, cunning of" hunters ", mobilities of the workforce, polymorphic simulations, findings that cause euphoria, both poetic and warlike" (CERTEAU, 1998, p. 47).

In this conception, what is imposed by the dominant order serves as support for another production, of an antidisciplinary character. With the use of tactics, subjects, from objects, information, spaces and symbols, build their own territory, even if itinerant, in the space of the other (CÓ; VICENTINI, 2018, p. 151), it is important to emphasize that we understand these subjects as something fluid, interchangeable, and not static in time. (MENEZES, JAYO and VICENTINI, 2019).

\section{THE ESTILERAS COLLECTIVE: ESCAPADES}

In his book, Da imperfeição, Greimas (GREIMAS, 2002) shows us the possibilities of breaking with the daily life of which Certeau also speaks. The book is divided into two parts: Fractures and Escapatories, in which the author puts us face to face with small aesthetic accidents of everyday life that change the mechanisms of meaning production of the subjects involved in them. These fractures in the subject's daily life produce a redimensioning of the aesthetic significance, and for this to occur, it is necessary that there is a disturbance in the subject's narrative, that is, an alteration in his daily routine. 
So, like the example of Junichiro Tanizaki's tale, Praise of the Shadow (TANIZAKI, 2008) - analyzed by Greimas (2002) -, the fracture occurs at the moment when the author describes the sensation of being surprised by the reflection the light of a candle in a dark room, and so sudden, makes it repeatedly hit the eyelids due to the increased incidence of light in contrast to the darkness (TANIZAKI, 2008).

At the Escapatories, Greimas shows us (...) "the exhausted aesthetics" that " $(. .$.$) following Lévi-Strauss, is one of the$ fundamental dimensions of culture - clothing culture - and asks us about these daily practices through the which aesthetics are manifested." (2002, p. 75). In this practice, parameters such as comfort, adequacy, convenience, desire to please are figured in lines, colors, attitudes, (...) endowed with conceptual meanings: simplicity, elegance, refinement. (2002, p. 77) that can be understood as "classificatory judgments", that is, belonging to an already established aesthetic code.

When we chose the Estileras collective as the object of study, we placed it in the status of a fracture, as Greimas says, because the subject's encounter with the collective's page on social media can be compared to this aesthetic accident that breaks with the production of instituted meaning by re-signifying his daily life, making another subject emerge, transformed into his status: from subject of state to subject of doing, an essential condition for the escape from the fracture. Let us explain. We understand that the collective makes us inquire about the shift in dress logic and its discourse. In the quick observation of the page on social media Instagram made available by the collective, it is possible to notice that we are facing a page with a proposal focused on fashion content, since the images are very similar to the fashion advertisements broadcast by the mainstream 
media. With more than 5,000 followers, the collective's page has the phrase, below your name, written: "you are the fashion designer". This small sentence modalizes the subject, in this case the enunciatory, into a "power-being" delegating to this subject the "power" to build himself as an agent of his own style of dress. In this way it is possible to perceive that there is the construction of a kind of "brand" Estileras. When we deepen the analysis, we noticed that the similarity with the mainstream media with fashion content, is restricted only to the poses adopted by the models and the production, creating an effect of meaning that at the same time that provokes us also distances us by the strangeness they cause. This thought-provoking movement is achieved by the recurring use of contrasts in visual language.

When the collective puts itself as an enunciator, it creates a language full of noise, contrasts of plastic formants in which colors, fabrics, shapes constitute a discourse that, at the same time, brings the enunciatee closer, also distances him.

In the rearrangement of shapes that refer to shoes, some even with the logo that characterizes them, do you consider them possible to be used in this new design, or not? And it is from this question, that it is said in passing, that it remains urgent for the enunciatee, the verification contract between enunciator / enunciatee is established.

The images below show possibilities of aesthetic arrangements that at first could be taken as something random, totally devoid of socially accepted dress code. The narrative undertaken by the subjects of the images leads us to the advertising images of fashion magazines, in which the enunciator Estileras appropriates the fashion discourse, but resignifies it in other aesthetic possibilities by subverting the uses and functions of garments. 
As an example of this, we analyze figure 4, which shows a white collar shirt, male, for use in social activities in which dress codes of greater rigidity are defined. The shirt is sleeveless and with the front cut out, that is, where the buttons would be for closing. In this space at the height of the chest is another pink shirt, cut at the height of the bust, which is attached to the white shirt by a hanger hanging from the collar of the white shirt. There is a disjunction between body and clothes in which you can see the contrast of the hanger, a rigid, metal object, in which the pink shirt is hung and placed in front of the body without the adjustment that would be achieved by modeling the clothes, in a clear attempt to subvert the object's function, since the hanger has the function of being hung in a suitable place to store clothes. The white shirt shows the model's chest, revealing part of her body and skin. There are no significant color contrasts, since the pink of the other shirt is a color with little saturation. The most evident contrast is due to the mathematical formants: fabric x metal x skin, in which even in a mediated relationship, one can intuit about the contrasts between these materials. Comfort, then, is apparently abandoned, as the metal is not molded to the body.

Picture 4. Coletivo Estileras

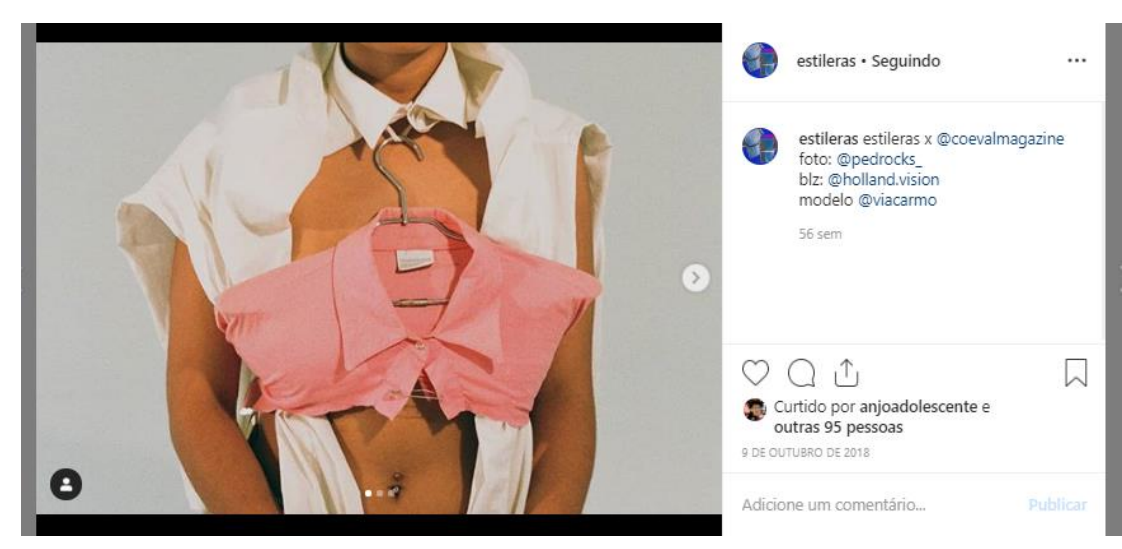

Source: Instagram, 2019. 
In the analysis of figure 4 we can consider the oppositions rigid (metal) $x$ flexible (fabric), the contrast of the chromatic formant and the oppositions of the diagonal lines of the collars that direct the route of the gaze, in a coming and going between the two shirts. Thus, when we stop at the observation of the image, we realize that in these relationships, the sensitive, the ambiguous, summons the intelligible of the enunciatee in the apprehension of the senses, provoking it, by showing an unusual way of dressing.

Also in figure 5 , there is this displacement of the object's initial function creating an effect of the subject's "disjunction" sense with the "fashion" value-object.

The enunciator persuades the enunciatee by redirecting his interpretation by using intertextuality, in which in the two examples he removes objects from his known territories and places them on another level of interpretation, as in figure 5 in which footwear designed for leisure activities, in which comfort is prioritized, and in which the material and design are subverted to another use, different from the initial proposal of the brand.

The material formant is once again summoned in the production of meaning, in which the leather (upper part of the shoe) is assembled with a superposition of materials arranged at random in order to remain firm on the foot. The sole is also made with overlapping plastic and other materials that apparently are residues of other shoes forming a kind of platform, using contrasting visual language resources.

Once again the aesthetic arrangement of these formants asks us about the comfort that should be provided by footwear, however, given the observable characteristics, this does not occur. This plane of expression in its dissonant and apparently disconnected materiality reiterates in the content 
plane the values of subversion, criticism and detachment from the fashion industry.

Picture 5. Estileras Collective

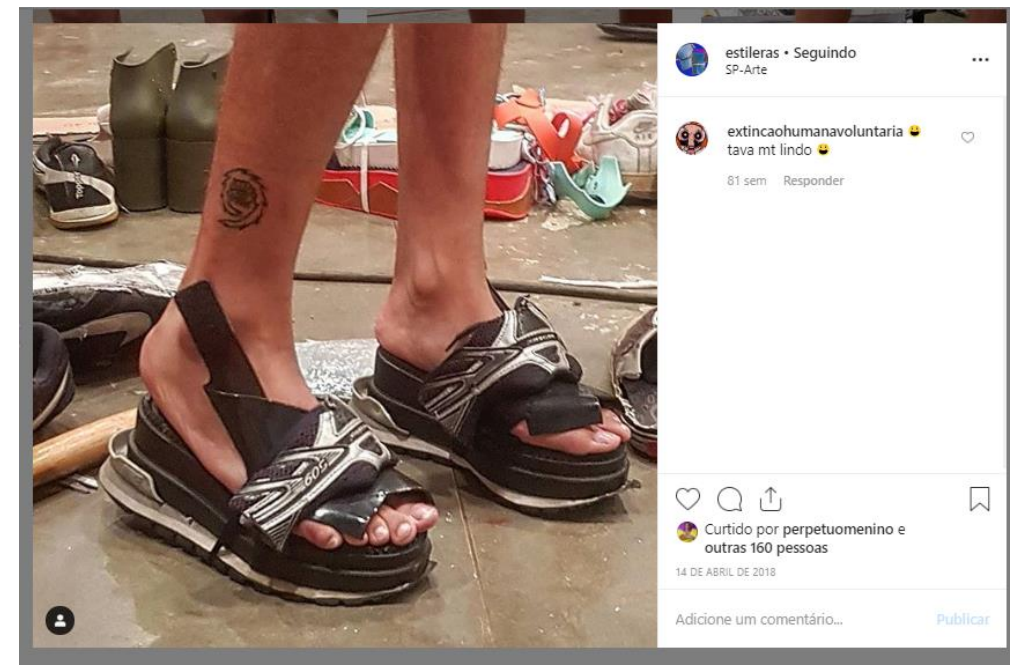

Source: Instagram, 2019.

The eidetic formant shows an artifact that puts feet on, but with irregular cutouts, which also leave doubts about its practicality and comfort. Thus, we have that these shoes do not lend themselves to their primary function of resting the feet, providing a safe walk. The black color chromatism of the plastics used provides a contrast with the white details and the skin tone of the wearer. As in the previous example, there is a tactile discontinuity in the order of the uncomfortable among the artifacts that should dress the body. The grammar that is revealed is, of course, of the order of the sensitive, between the recipient-estileras and the recipient-follower because it only happens through the aesthetic qualities evidenced in the expression plane; thus, suddenly, the possibility of rearranging one's appearance is being revealed.

Accustomed that we are to advertising discourses in which there is a balance of languages, these dissonant statements cause strangeness and invite us to rethink not only their uses, 
but the way that the visibility regimes established by fashion, of a "socialized and political self" can be discussed in various communication situations, in different types of discourse.

Another point to be highlighted in the analysis is that the model body presented is fractioned. It does not show itself in full, it is not placed in a particular scenario, specially arranged for that. The resulting sense effects are random, as if the photos were taken without much concern with a photographic language format.

At this point we return to Foucault in order to base our reflections because, already in the subversion of the functional and ideal use for which the pieces were designed, the collective Estileras tries to take control of his own body, by not submitting to the disciplinary logic of fashion system.

\section{FINAL CONSIDERATIONS}

The fashion system can be thought of as a disciplinary device that seeks to docilize the bodies subjected to it, but whenever there is power, it is assumed that there is also resistance, and at this point the Estileras collective proposal fits.

Seeking to understand the meaning regimes that govern these enunciators, we are faced with an interesting question, as it is possible to deduce from these analyzes that both the enunciator-Thassia Naves and Camila Coelho dress for the other, in a symbolic dress, but in the case of Estileras, the relation with the clothes is a little different, it can be said that it would be an object dressing, as we will explain next. In Landowski's visibility regimes we can put it this way: 


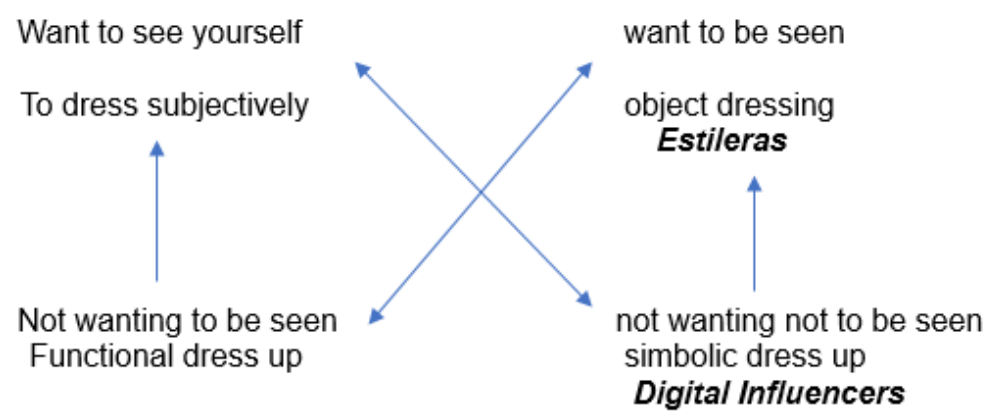

This semiotic square proposed from what Garcia (2005) studied about the visibility regimes in the use of lingerie seems to us to be quite appropriate for the problem that we pose here, since in object dressing, the collective Estileras, proposes the encounter with the Another, and in symbolic dressing, the digital influencer proposes, by dressing, to be someone in the social.

Resuming our initial positions on the aspect of escape that represents the collective's page on social media, it is possible to infer, in view of these analyzes, that the enunciator Estileras is antagonistic to the dictates established by the fashion industry, proposing a critique of what is defined as aesthetically accepted in contemporary society.

Thus, when faced with the collective page, the enunciatee gets in touch with the lived sense, the immediate aesthetic apprehension, because what is presented escapes, even if momentarily, from the intelligible. There are no written verbal statements proposing any kind of approximation. The image is presented without much explanation, leaving the enunciatee to navigate without direction. It also proposes, in terms of Landowski's sociosemiotics, a regime of interaction in the order of adjustment, in which the making-feeling is a regime between equals, in which the dynamics are coordinated according to the sensitivities of each one. 
By not adhering to socially accepted values, enunciator / enunciatee create a rupture in which the political subject is repositioned in a new social media space-time.

\section{REFERENCES}

BERGAMO, Alexandre. A experiência do status: roupa e moda na trama social. São Paulo: Editora Unesp, 2007. 226 p.

CERTEAU, Michel de. A invenção do cotidiano: artes de fazer. 3. ed. Petrópolis: Vozes, 1998. 351 p. Tradução de Ephraim Ferreira Alves.

CÓ, Yasmin Alexandre; VICENTINI, Cláudia Regina Garcia. A subversão na moda: o pastiche como território de criação. In: DESIGNA 2018 - INTERNATIONAL CONFERENCE ON DESIGN RESEARCH, 7., 2018, Covilhã, Portugal. DESIGNA 2018 TERRITORY PROCEEDINGS. Covilhã, Portugal: Labcom.ifp/ Ars, 2018. p. 145 - 152. Disponível em: http://labcomifp.ubi.pt/book/319. Acesso em: 14 ago. 2019.

FECHINE, Yvana. Uma proposta de abordagem sensível na TV. XV COMPÓS. Bauru, 2006.

FIORIN, José Luiz. Linguagem e ideologia. 6. ed. São Paulo: Editora Ática, 1998.

FOUCAULT, Michel. Microfísica do poder. 23. ed. Rio de Janeiro: Graal, 2007. 295 p. Original publicado em 1975.

FOUCAULT, Michel. Vigiar e punir: nascimento da prisão. 20. ed. Petrópolis: Vozes, 1987. 288 p. Tradução de Raquel Ramalhete.

GARCIA, Cláudia Regina. Estudo semiótico das lingeries na construção dos regimes de visibilidade da mulher brasileira: conceituações do formante matérico. Pontifícia Universidade Católica. São Paulo, 2005.

GREIMAS, Algirdas.Julien. Da imperfeição. 1.ed. São Paulo: Hacker Editores, 2002.

KAWAMURA, Yuniya. Fashion-ology: an introduction to fashion studies. Nova York: Berg, 2005. 124 p.

KAWAMURA, Yuniya. The Japanese revolution in Paris fashion. New York: Berg, 2004. 198 p.

LANDOWSKI, Eric. A sociedade refletida. São Paulo: EDUC/Pontes, 1992.

LANDOWSKI, ERIC. Presenças do outro. Trad. Mary Amazonas Leite de Barros. São Paulo, Perspectiva, 2002.

LANDOWSKI, ERIC. Sociossemiótica: uma teoria geral do sentido. Rev. Galáxia. São Paulo, 2014.

MENESES, E. JAYO, M. VICENTINI, C.R.G. Entre demonstrar e dissimular: notas sobre o papel do vestuário na expressão de 
homossexualidades masculinas na história do Brasil. In: Revista Caribeña de Ciencias Sociales, 2019.

OliVeIRA, Ana. Cláudia. (org.) Semiótica Plástica. São Paulo: Hacker Editores, 2004.

RANCIÈRE, Jacques. A partilha do sensível: estética e política. 2. ed. São Paulo: Exo, 2009. 69 p. Tradução de Mônica Costa Netto.

SILVEIRA, Vanessa.Rozan. Corpos e belezas no Instagram: em busca de likes. Dissertação de Mestrado. PUC-SP, 2017.

SODRÉ, Muniz. Logos e pathos: a razão e a paixão no espaço conceitual da comunicação e novas tecnologias. Em CAPARELLI, Sérgio, SODRÉ, Muniz e SQUIRRA, Sebastião (orgs.) Livro da XIII Compós: Comunicação Revisitada. Porto Alegre, Sulina, 2005.

TANIZAKI, Junichiro. Elogio da sombra. 1. ed. São Paulo: Relógio d'Água, 2008. Original publicado em 1933.

VICENTINI, Cláudia Regina Garcia.; CASTILHO, Kathia. Design do corpo, design da moda: uma análise semiótica In Design de Moda: olhares diversos. Dorotéia Barduy Pires (org.) São Paulo: Ed. Letras e Cores, 2008.

VICENTINI, Cláudia Regina Garcia. Ferramentas e metodologia de projeto aplicados na criação de produtos para indústria têxtil-confecção. Tese de Doutorado. UNICAMP, 2010. 